\title{
Determination of Micro Minerals in Milk from Farm and Pasture-Reared Cow, Goat and Camel; using Inductively Coupled Plasma-Optical Emission Spectrometry
}

\author{
SIRELKHATIM BALLA ELHARDALLOU ${ }^{1}$ and ASHRAF YEHIA EL-NAGGAR ${ }^{1,2}$ \\ 'Department of Chemistry, Faculty of Science, Taif University, KSA. \\ 2. Egyptian Petroleum Research Institute, Nasr City, Cairo, Egypt. \\ ${ }^{*}$ Corresponding author E-mail drhardallou@yahoo.com \\ http://dx.doi.org/10.13005/ojc/320138
}

(Received: December 29, 2015; Accepted: March 06, 2016)

\begin{abstract}
This study covers raw fresh milk of cow, goat and camel (farm and pasture-reared), in addition to two brands of commercial milk samples, liquid milk of powder origin and drinking yoghurt samples. Camel milk showed a relatively lower $\mathrm{pH}$ range $(6.15$ - 6.46) compared cow, goat and commercial milk. The $\mathrm{pH}$ of drinking yoghurt was found (4.35 - 4.47).Microwave digestion, was selected followed by mineral analysis using Inductively Coupled Plasma-Optical Emission Spectrometry. Micro minerals; $\mathrm{Cd}, \mathrm{Cr}, \mathrm{Cu}, \mathrm{Fe}, \mathrm{Mn}$ and $\mathrm{Pb}$, ranged from not detected to $23.4 \pm 0.52 \mathrm{mg} / \mathrm{L}$ for $\mathrm{Fe}$ while $\mathrm{Sr}(0.32 \pm 0.005$ $-2.51 \pm 0.043 \mathrm{mg} / \mathrm{L})$ and $\mathrm{Zn}(1.58 \pm 0.01-8.91 \pm 0.14 \mathrm{mg} / \mathrm{L})$ in all milk samples.
\end{abstract}

Key words: cow milk; goat milk; camel milk; microwave digestion; micro minerals; ICP-OES.

\section{INTRODUCTION}

The demand for dairy products is increasing in Saudi Arabia, due to improved living status, nutritional awareness and availability of milk and milk product sources. These products are varying in composition, texture and taste. Milk consumption varies, worldwide from about $180 \mathrm{~kg}$ yearly per capita in Finland to less than $50 \mathrm{~kg}$ in Japan and China ${ }^{1}$. In addition to cow milk as a main source for consumption, in Saudi Arabia; camel and goat milk are also widely available, particularly in rural areas. Raw camel milk usually consumed without pasteurization, while cow and goat milk, after boiling.

Proximate analysis of cow, goat and camel milk showed a protein \% of $3.42,3.26$ and 3.26 respectively; a fat content of $4.09,4.07$ and 3.80 respectively and lactose content of $4.82,4.51$ and 
4.30 respectively ${ }^{2-7}$. Water content of whole cow, goat and camel milk at Kingdom of Bahrain, reported as $87.4,87.0$ and $87.5 \%$, respectively ${ }^{8}$.

The contribution of milk and milk products to the diet in western countries is significant for sodium, potassium, chloride, calcium, phosphorus, zinc and iodine ${ }^{9}$.

Minerals at nutritional standard concentrations in food are necessary for human health. The consumption of food with high mineral contents can cause gastric irritation and diarrehea ${ }^{10}$ and might affect other organ systems.

Determination of elements in foods is dependent upon the sample digestion, because of the risks of contamination or losses of analytes ${ }^{11}$. Usually, dry ashing and wet or conventional (hot- plate) methods ${ }^{12}$ have been used for mineral analyses but these procedures are time-consuming and give relatively low concentration readings. Microwave digestion provides rapid analysis and satisfactory results for metals in food ${ }^{13-15}$.

Minerals determination is an active topic in analytical science. The choice of an analytical technique, is related to a number of factors, including: (1) susceptibility to matrix effects (2) the range of elements covered (3) the detection limits.

Examples of methods are flame photometer, Atomic Absorption Spectrophotometer (AAS) ${ }^{16}$ and Inductively coupled Plasma- Optical Emission Spectrometry (ICP-OES) ${ }^{17}$. The latter, is an established analytical technique with large linear dynamic range, low detection limits, high precision and accuracy, which offers automation, rapid multi-

Table 1: The program of microwave digestion

\begin{tabular}{|c|c|c|c|c|}
\hline Stage & $\begin{array}{c}\text { Power } \\
\mathrm{P}(\mathrm{W})\end{array}$ & $\begin{array}{c}\text { Heating-up } \\
\text { time } \\
\mathrm{t}(\mathrm{min})\end{array}$ & $\begin{array}{c}\text { Operating } \\
\text { temperature } \\
\mathrm{T}\left({ }^{\circ} \mathrm{C}\right)\end{array}$ & $\begin{array}{c}\text { Operating } \\
\text { time } \\
\mathrm{t}(\mathrm{min})\end{array}$ \\
\hline 1 & 760 & 5 & 120 & 3 \\
\hline 2 & 760 & 3 & 150 & 3 \\
\hline 3 & 760 & 5 & 150 & 15 \\
\hline
\end{tabular}

Table 2: ICP-OES operating conditions

\begin{tabular}{|c|c|}
\hline RF (MHz) & 40.68 \\
\hline RF power (W) & 1300 \\
\hline Gas flow rate (/min) & \\
\hline Plasma gas & 15.0 \\
\hline Auxiliary gas & 0.2 \\
\hline Nebulizer gas & 0.8 \\
\hline Sample uptake rate (mi/min) & 1.5 \\
\hline Observation height (mm) & 15 \\
\hline Plasma viewing & Radial \\
\hline Read time (s) & 15 \\
\hline Delay time (s) & 30 \\
\hline Wash time (s) & 30 \\
\hline
\end{tabular}

element analysis for the determination of major, minor and trace elements in milk samples.

In this study, milk samples are obtained from Western region of Saudi Arabia, Taif province, except milk of pasture reared cows which was obtained from Western Sudan, of similar lands and climate. Raw and fresh milk of Cow (Bos Taurus); Goat (Capra aegagrus hircus) and Camel (Camelus dromedarius); farm and pasture-reared; in addition to commercial milk samples and milk products; are evaluated for micro minerals content.

\section{MATERIALS AND METHODS}

This study, carried out in Taif University, Western Saudi Arabia from August to November 
2015. Twelve milk and milk product samples collected:

1) Fresh, raw cow milk (farm -rearing); 2) Fresh, raw cow milk (pasture-rearing);3) Fresh, raw goat milk (farm -rearing); 4) Fresh, raw goat milk (pasture-rearing); 5) Fresh, raw camel milk (farm -rearing); 6) Fresh, raw camel milk (pasture-

\section{Table 3: The pH of raw milk of farm and pasture-reared cow, goat and camel; commercial fresh milk (samples 1 and 2), liquid milk prepared from milk powder (samples 3 and 4) and drinking yoghurt (samples 1 and 2)}

\begin{tabular}{lcc}
\hline $\begin{array}{l}\text { Raw milk source; } \\
\text { fresh milk and } \\
\text { yoghurt samples }\end{array}$ & pH \\
\hline Cow (Farm fed) & $6.68(6.69,6.68,6.67)$ \\
Cow (Pasture fed) & $6.78(6.79,6.78,6.77)$ \\
Goat (Farm fed) & $6.45(6.46,6.45,6.44)$ \\
Goat (Pasture fed) & $6.58(6.54,6.60,6.61)$ \\
Camel (Farm fed) & $6.46(6.45,6.46,6.47)$ \\
Camel (Pasture fed) & $6.15(6.13,6.15,6.17)$ \\
Commercial Sample 1 & $6.69(6.70,6.67,6.69)$ \\
Commercial Sample 2 & $6.73(6.73,6.72,6.73)$ \\
Commercial Sample 3 & $6.59(6.59,6.6,6.59)$ \\
Commercial Sample 4 & $6.58(6.57,6.58,6.59)$ \\
Commercial Yoghurt 1 & $4.35(4.36,4.33,4.35)$ \\
Commercial Yoghurt 2 & $4.47(4.48,4.47,4.47)$ \\
\hline
\end{tabular}

rearing); 7) Commercial fresh cow milk, Sample 1; 8) Commercial fresh cow milk, Sample 2; 9) Commercial liquid milk, whole, prepared from cow's milk powder, Sample 3; 10) Commercial liquid milk, fat free, prepared from cow's milk powder Sample 4; 11) Commercial drinking yoghurt (cow milk source) Sample 1; 12) Commercial drinking yoghurt (cow milk source), Sample 2.

\section{Reagents and glass wares}

All reagents and chemicals were of analytical grade obtained from Merck (Darmstadt, Germany, www.merck.de). Nitric acid of analytical grade R. Was used, 69-72 \% (m/m) HNO3 (d = $1.41-1.51 \mathrm{~kg} \mathrm{l}-1$ ), De-ionized doubly distilled water (DDDW) was also used throughout the analyses for preparing reagents, standard and sample solutions. DDDW also used for washing and rinsing of all apparatus and glassware. Acid-washed polyethylene bottles used for preparing and storing solutions. All solutions were stored in the refrigerator until needed for analysis.

\section{Microwave digestion using MARS 5 instrument} The MARS 5, instrument was programmed for digestion as shown in Table 1. The program involved $760 \mathrm{~W}$, power at $120{ }^{\circ} \mathrm{C}$ for $5 \mathrm{~min}, 760 \mathrm{~W}$ at $150 \stackrel{\circ}{\circ}$ for $15 \mathrm{~min}$. and $0 \mathrm{~W}$ for $30 \mathrm{~min}$ to $\mathrm{cool}$ down polypropylene volumetric flasks (Corning NY Mexico). The contents, then diluted with de-ionized water and analyzed ${ }^{18}$.

Table 4: Concentration (mg/L) of micro minerals (Cd, $\mathrm{Cr}, \mathrm{Cu}, \mathrm{Fe}, \mathrm{Mn}, \mathrm{Pb}, \mathrm{Sr}$ and $\mathrm{Zn}$ ) in milk from farm and pasture -reared cow $[1,2]$; goat $[3,4]$ and camel $[5,6]$.

\begin{tabular}{|c|c|c|c|c|c|c|c|c|}
\hline & Cd & $\mathrm{Cr}$ & $\mathrm{Cu}$ & $\mathrm{Fe}$ & Mn & $\mathrm{Pb}$ & $\mathrm{Sr}$ & $\mathrm{Zn}$ \\
\hline \multirow[t]{2}{*}{1} & $0.025 b$ & $0.732 c$ & ND & $23.32 a$ & 0.575 & $0.167 b$ & $1.452 b$ & $7.814 a$ \\
\hline & \pm 0.024 & \pm 0.005 & & $23.32 a$ & \pm 0.002 & \pm 0.010 & \pm 0.014 & \pm 0.141 \\
\hline \multirow[t]{2}{*}{2} & ND & ND & ND & $1.42 \mathrm{c}$ & ND & ND & $1.141 \mathrm{c}$ & $7.437 a$ \\
\hline & & & & \pm 0.076 & & & \pm 0.003 & \pm 0.140 \\
\hline \multirow[t]{2}{*}{3} & $0.094 a$ & $6.656 a$ & ND & $13.05 b$ & 0.406 & $0.266 a$ & $2.294 a$ & $2.964 b$ \\
\hline & \pm 0.032 & \pm 0.581 & & \pm 1.484 & \pm 0.005 & \pm 0.004 & \pm 0.040 & \pm 0.140 \\
\hline \multirow[t]{2}{*}{4} & $0.009 \mathrm{~b}$ & ND & ND & $1.85 \mathrm{c}$ & ND & ND & $1.172 \mathrm{c}$ & $3.405 b$ \\
\hline & \pm 0.018 & & & \pm 0.410 & & $\mathrm{C}$ & \pm 0.004 & \pm 0.049 \\
\hline \multirow[t]{2}{*}{5} & $0.089 a$ & $0.193 c$ & ND & ND & ND & ND & $1.517 b$ & $1.580 \mathrm{c}$ \\
\hline & \pm 0.065 & \pm 0.084 & & & & & \pm 0.015 & \pm 0.039 \\
\hline \multirow[t]{2}{*}{6} & $0.007 b$ & ND & $0.265 a$ & $0.049 d$ & ND & ND & $0.885 d$ & 7.39a \\
\hline & \pm 0.012 & $d$ & \pm 0.088 & \pm 0.036 & & & \pm 0.002 & \pm 0.144 \\
\hline
\end{tabular}

*Same letter in any column (mineral) signs for non-significant difference. 
From each. $1.5 \mathrm{ml}$ sample was taken in $250 \mathrm{ml}$ beaker, heated on hot surface (about $95^{\circ} \mathrm{C}$ ) to near dryness. $12 \mathrm{ml}$ nitric acid followed by $2 \mathrm{ml}$ hydrogen peroxide were used to transfer the sample from the beaker to the poly-tetrafluoroethylene (PTFE) (MF 100) digestion vessel.
After microwave digestion and cooling for 30 minutes, the contents were transferred to a 250 $\mathrm{mL}$ beaker, heated on a hot plate at temperature not exceeding $95^{\circ} \mathrm{C}$, up to about $1 \mathrm{ml}$ is remaining in the beaker. After cooling, about $10 \mathrm{ml}$ double distilled water (DDW) added and transferred to a 25 $\mathrm{ml}$ volumetric flask; more DDW added to rinse the

Table 5: Concentration ( $\mathrm{mg} / \mathrm{L}$ ) of micro minerals ( $\mathrm{Cd}, \mathrm{Cr}, \mathrm{Cu}, \mathrm{Fe}, \mathrm{Mn}, \mathrm{Pb}, \mathrm{Sr}$ and $\mathrm{Zn}$ ) in investigated commercial milk samples,1,2,3 and 4; milk products (drinking yoghurt) 1 and 2.

\begin{tabular}{ccccccccc}
\hline & Cd & Cu & Fe & Pb & Sr & Zn & Mn & Cr \\
\hline Milk Sample 1 & $0.223 \mathrm{a}$ & $1.658 \mathrm{a}$ & $21.68 \mathrm{a}$ & $3.338 \mathrm{a}$ & $1.306 \mathrm{a}$ & $2.36 \mathrm{c}$ & $0.224 \mathrm{c}$ & $0 \mathrm{e}$ \\
& \pm 0.007 & \pm 0.011 & \pm 3.070 & \pm 0.080 & \pm 0.017 & \pm 4.469 & \pm 0.009 & \pm 0 \\
Milk Sample 2 & $0.027 \mathrm{e}$ & 0.0 & 0.0 & $0.040 \mathrm{e}$ & $1.164 \mathrm{~b}$ & $2.56 \mathrm{~b}$ & $0.502 \mathrm{a}$ & $0.782 \mathrm{c}$ \\
& \pm 0.001 & $\mathrm{~d}$ & $\mathrm{~d}$ & \pm 0.007 & \pm 0.051 & \pm 0.038 & \pm 0.373 & \pm 0.016 \\
Milk Sample 3 & $0.042 \mathrm{~d}$ & 0.0 & 0.0 & $0.434 \mathrm{~b}$ & $0.223 \mathrm{c}$ & $2.71 \mathrm{~b}$ & 0.0 & $0.224 \mathrm{~d}$ \\
& \pm 0.001 & $\mathrm{~d}$ & $\mathrm{~d}$ & \pm 0.019 & \pm 0.005 & \pm 0.692 & $\mathrm{~d}$ & \pm 0.007 \\
Milk Sample 4 & $0.027 \mathrm{e}$ & 0.0 & $11.517 \mathrm{c}$ & 0.0 & $1.173 \mathrm{~b}$ & $2.342 \mathrm{e}$ & $0.603 \mathrm{a}$ & $1.947 \mathrm{a}$ \\
& \pm 0.032 & $\mathrm{~d}$ & \pm 0.119 & $\mathrm{f}$ & \pm 0.045 & \pm 0.032 & \pm 0.051 & \pm 0.142 \\
Milk Produt 1 & $0.054 \mathrm{c}$ & $0.985 \mathrm{~b}$ & $16.17 \mathrm{~b}$ & $0.256 \mathrm{c}$ & $1.153 \mathrm{~b}$ & $7.64 \mathrm{a}$ & $0.318 \mathrm{~b}$ & $1.173 \mathrm{a}$ \\
& +0.005 & +0.093 & +2.423 & +0.008 & +0.054 & +0.210 & +0.009 & +0.013 \\
Milk Product 2 & $0.083 \mathrm{~b}$ & $0.484 \mathrm{c}$ & 0.0 & $0.146 \mathrm{~d}$ & $1.521 \mathrm{~b}$ & $2.00 \mathrm{~d}$ & 0.0 & $1.126 \mathrm{~b}$ \\
& +0.005 & +0.008 & $\mathrm{~d}$ & +0.041 & +0.076 & +0.045 & $\mathrm{~d}$ & +0.010 \\
& & & & & & & & \\
\hline
\end{tabular}

${ }^{\star}$ Same letter in any column (mineral) signs for non-significant difference.

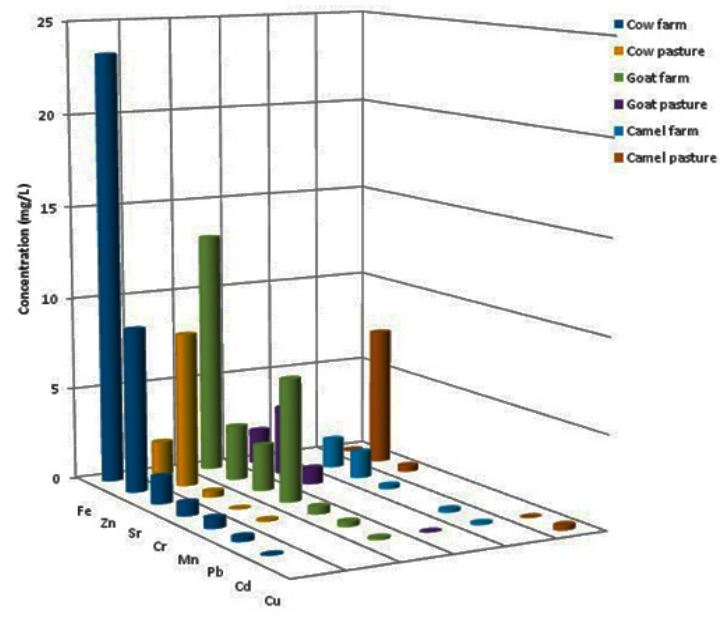

Fig. 1: Concentration (mg/L) of micro minerals ( $\mathrm{Cd}, \mathrm{Cr}, \mathrm{Cu}, \mathrm{Fe}, \mathrm{Mn}, \mathrm{Pb}, \mathrm{Sr}$ and $\mathrm{Z}$ ) in milk of farm or pasture -reared cow, goat and camel milk

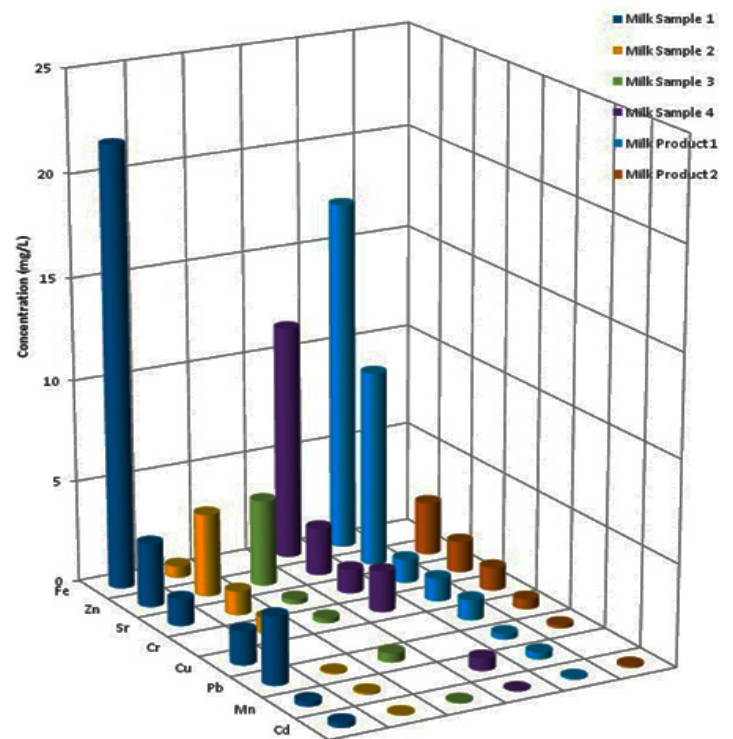

Fig. 2: Concentration (mg/L) of micro minerals ( $\mathrm{Cd}, \mathrm{Cr}, \mathrm{Cu}, \mathrm{Fe}, \mathrm{Mn}, \mathrm{Pb}, \mathrm{Sr}$ and $\mathrm{Zn}$ ) in investigated commercial milk samples and milk products (drinking yoghurt) 
beaker and complete the flask to mark; ready for analysis. Blank solutions prepared by the procedure above without sample ${ }^{18}$, with modifications).

\section{Inductively Coupled Plasma-Optical Emission Spectrometry (ICP-OES) Instrument and conditions}

A Varian 725-ES inductively coupled plasma-optical emission spectrometer (ICP-OES), with radial viewing configuration (Perkin Elmer, USA), was used to analyze the standard and the sample solutions of $\mathrm{Cd}, \mathrm{Cr}, \mathrm{Cu}, \mathrm{Fe}, \mathrm{Mn}, \mathrm{Pb}, \mathrm{Sr}, \mathrm{Zn}$. The ICP-OES operating conditions well optimized and carefully selected in order to maximize the sensitivity for the desired elements and to obtain the best precision and accuracy. Details of the operating conditions summarized in Table 2.

To ensure that no contamination and/or loss of elements occurs during sample preparations and measurement methodology, a multi-element standard solution was prepared in DDDW and treated in a similar way to samples solutions. Table 4 and Figure 1 show the concentration values of micro minerals ( $\mathrm{Cd}, \mathrm{Cr}, \mathrm{Cu}, \mathrm{Fe}, \mathrm{Mn}, \mathrm{Pb}, \mathrm{Sr}$ and $\mathrm{Zn}$ ) in raw milk from farm and pasture -reared cow; goat and camel.

\section{Statistical Analysis}

Statistical analysis was carried out by Sigma Stat for Windows version 2.0 (Jandel Scientific, USA). Data expressed as Mean \pm SEM. Statistical analysis was performed using one way analysis of variance followed by Tukey post hoc test. The criterion for statistical significance was $p<0.05$. Results expressed as $x \pm s$, where $x$ mean values and $s$ is standard deviation.

\section{RESULTS AND DISCUSSION}

\section{pH Determination}

The instrument; Microprocessor $\mathrm{pH}$ meter (Hanna, pH 211) used in this study.

As shown in Table 3, the $\mathrm{pH}$ range of raw fresh cow (farm and pasture-reared) milk and commercial cow milk samples is $(6.45-6.78)$. Goat milk $\mathrm{pH}$ range (6.45-6.58) while camel milk showed a relatively lower $\mathrm{pH}$ range $(6.15-6.46)$. The $\mathrm{pH}$ of drinking yoghurt found (4.35 - 4.47).
Table 5 and Figure 2 show the concentration values of micro minerals $(\mathrm{Cd}, \mathrm{Cr}, \mathrm{Cu}, \mathrm{Fe}, \mathrm{Mn}, \mathrm{Pb}$, $\mathrm{Sr}$ and $\mathrm{Zn}$ ) of commercial milk samples, 1 and 2; sterilized milk; samples prepared from milk powder; sample 3 (fat free) and sample 4 (whole); in addition to milk products (drinking yoghurt) samples 1 and 2.

For minerals of investigated raw milk samples, correlation factors of $\mathrm{Fe}$ and $\mathrm{Sr}(\mathrm{r}=0.80)$; $\mathrm{Cd}$ and $\mathrm{Mn}(\mathrm{r}=0.84)$. For commercial milk samples and products: $\mathrm{Fe}$ and $\mathrm{Zn}(\mathrm{r}=0.92) ; \mathrm{Cd}$ and $\mathrm{Pb}(\mathrm{r}=0.96)$; $\mathrm{Cd}$ and $\mathrm{Cu}(\mathrm{r}=0.84)$ indicated strong correlations between concentration of these minerals.

The $\mathrm{Cd}-\mathrm{Cu}$ and $\mathrm{Cd}-\mathrm{Mn}$ correlations were noteworthy for the association of a highly toxic element $(\mathrm{Cd})$ with nutritionally important elements (Cu and $\mathrm{Mn}$ ). $\mathrm{Cd}, \mathrm{Cu}, \mathrm{Pb}, \mathrm{Mn}$, and $\mathrm{Cr}$ concentrations in raw milk of pasture-reared cow, goat and camel are notably lower than those farm-reared. This can be attributed to farm utensils, which possibly contain these minerals.

Variations in milk mineral content, can be attributed to animal breed differences, feeding and analytical procedures ${ }^{19}$ in addition to water intake ${ }^{20}$.

Present study show that milk can contribute a considerable proportion of the supply of micro minerals in the human diet.

\section{CONCLUSION}

The selection of microwave digestion for sample preparation and ICP-OES for determination of cadmium, chromium, copper, iron, manganese, lead, strontium and Zinc as micro minerals proved relevant for the analysis of raw milk, fresh milk and drinking yoghurt. Mineral concentrations were found within recommended values. The concentrations of minerals in studied samples were relatively: $Z n>$ $\mathrm{Sr}>\mathrm{Fe}$. These results are comparable to previous studies and confirm the nutritional contribution of milk and drinking yoghurt to the human diet, with concentration values below tolerable upper levels. 


\section{ACKNOWLEDGMENT}

This research was financed by the Deanship

for Scientific Research, Taif University, KSA.

\section{REFERENCES}

1. Saxelin, M.; Korpela, R. and Mayra-Makinen, A. 2003. Introduction: classifying functional dairy products. In: Mattila-Sandholm T, Saarela M, editor. Functional dairy products. Woodhead Publishing Limited, UK;.. 1-16.

2. Auldist M.J.; Thomson, N.A.; Mackle, T.R.; Hill, J.P.; Prosser, C.G. Effects of pasture allowance on the yield and composition of milk from cows of different â-lactoglobulin phenotypes. J. Dairy Sci. 2000. 83(9):206974.

3. Bernacka, H. Effect of breed and feeding season on the nutritive quality of goat's milk. Folia Biol (Cracow). 2000. 53:99-102.

4. Bernacka, H. Cytological quality of goat milk on the basis ofthe somatic cell count. J Cent Eur. Agric 2006. 7(4):773-778.

5. Calsamiglia, S.; Hernandez, B.; Hartnell, G.F. and Phipps, R. Effects of corn silage derived from a genetically modified variety containing two transgenes on feed intake, milk production, and composition, and the absence of detectable transgenic deoxyribonucleic acid in milk in Holstein dairy cows. J. Dairy Sci. 2007. 90(10):4718-23.

6. Abu-Lehia, I.H. Composition of camel milk. Milchwissenschaft. 1987. 42:368-71.

7. Abu-Lehia, I.H.; Al-Mohiezea, I.S. and ElBehry, M. Studies on the production of ice cream from camel milk products. Aust J Dairy Tech. 1989. 44: 31-4.

8. Al-Attas, A. S. (2008). Determination of essential elements in milk and urine of camel and in Nigella sativa seeds. Arabian Journal of Chemistry, 1, 123-129.

9. Musaiger, A.o. First edition. 2011.

10. Flynn, A. Minerals and trace elements in milk. Adv. Food Nutr. Res., 1992. 36: 209-252.

11. Blunden, S. and Wallace, T. Tin canned food: a review and understanding of occurrence and effect. Food Chem. Toxicol. 2003. 41:
1651-1662.

12. Fuente, M. A. and Juarez, M. Determination of phosphorus in dairy products by sample wet digestion in a microwave oven. Anal. Chim. Acta. 1995. 309: 355-359.

13. Forrest H. Nielsen,(1997), Boron in human and animal nutrition, Plant and Soil, 193, 1-2, 199-208.

14. Borkowska-Bumecka, J.; Szmigiel, E. and Zyrnicki, W. (1996). Determination of Major and Traee Elements ill Powdered Milk by Inductively Coupled PlasmaAtomicEmission Spectrometry. Chem. Anal. (Warso) 41: 625 - 634.

15. Kira, C. S., and Maihara, V. A. Determination of major and minor elements in dairy products through inductively coupled plasma optical emission spectrometry, after wet partial digestion and neutron activation analysis. Food Chem. 2007. 100: 390-395.

16. Khan, N.; Choi, J.Y. andNho, E.Y. Determination of mineral elements in milk products by Inductively Coupled PlasmaOptical Emission Spectroscopy. Anal. Letters. 2014. 47 (9): 1606 - 1613.

17. Yang, L.I.; Yanlan, L.I.;Guoxjxj, X.M. and Yan, Q. J. Chilean Chem. Soc. 2013. Online ISSN 0717-9707

18. Smedley, P. L. andKinniburgh, D. G. Behaviour and distribution of Arsenic in natural waters. Appl. Geochemistry. 2002. 17: 517-568.

19. Momen, A. A. and Lilly, B. E. Trace Elements in Smoker's and Non-Smoker's Urine Samples. J. Ar. and Sci. 2010. 9: 27-40.

20. Khan, N.; Joeng, I.S.; Hwang, .I.M.; Kim, J.S.; Choi, S.H.; Nho, E.Y. and Choi, J.Y. Method validation for simultaneous determination of chromium, molybdenum and selenium infant formulas by ICP-OES and ICP-MS. Food Chem. 2013. 141: 3566 - 3570.

21. Mehaia, M. A., Hablas, M. A., Abdel-Rahman, 
K. M., \& El-Mougy, S. A. Milk composition of Majaheim, Wadah and Hamra camels in Saudi Arabia. FoodChem. 2009 52: 115122.
22. Haddadin, M. S. Y., Gammoh, S. I., \& Robinson, R. K. Seasonal variations in the chemical composition of camel milk in Jordan. J. Dairy Res.2008. 75: 8-12. 